\title{
Field Efficacy of Steinernema carpocapsae Against Lima Bean Pod Borer, Etiella zynckenella Treitschke, Attacking Groundnut
}

\author{
Dwinardi Apriyanto $^{\# 1}$, Nadrawati ${ }^{\# 2}$, Tri Sunardi ${ }^{\# 3}$, Dotti Suryati ${ }^{*}$ \\ \# Department of Plant Protection, University of Bengkulu, Bengkulu, 38371, Indonesia \\ E-mail: ${ }^{1}$ kangdwi2010@gmail.com, ${ }^{2}$ nadrahpt@ymail.com, 3 trisunardi@yahoo.co.id \\ * Department of Plant Culture, University of Bengkulu, Bengkulu, 38371, Indonesia \\ E-mail:dottisuryati@yahoo.com
}

\begin{abstract}
Lima bean pod borer (LBPB), Etiella zynckenella Trietschke, is major insect pest of soybean in Indonesia. Currently it was also reported attacking groundnut in some parts of Sumatera causing serious yield loss. Insecticide treatment is not only ecologically unsafe, but also is not practical due to concealed behavior of the larvae within pods below soil surface. Systemic insecticide might be so but unsafe as it might leave unaccepted residue in harvested pods. It is clear that safer more effective technology such as biological control is badly needed. A Field study was conducted at the University of Bengkulu Research Station in 2012-2013. The objectives was to determine the effectiveness of non local strain of entomopathoegen nematode (EPN), Sterinenema carpocapsae, to control LBPB attacking groundnut. Groundnut seeds were sewed in plots which were later treated with $S$. carpocasae produce by Biological Control Laboratory University of Jember at the dose of $500.000 \mathrm{JI} \mathrm{m}^{-2}$. EPN was sprayed upon plants and soil surface twice at plant age of 45 and 65 days after sewing (DAS). There were insecticide treatment and control plots as comparison. Observations of damaged pods and the presence of LBPB larvae were done at plant age of 63, 77, 90 DAS and at the haevesting date. Data were subjected to analysis of variance and the means of damaged pods were separated with least significant different (LSD). The result revealed that in two years study, damaged pods consistently tended to be less in plots treated with $S$. carpocasae or insecticide than those in controls, indicating that it might be effective against PLPB. The lack of significant different between EPN treated and control plots might be as a result of low percentages of EPN larval survival due shipment problem (i.e. inappropriate packaging and long transportation that toke several days) or it might be that the strain was less adapted yet to local conditions. I speculate that local strain of EPN might be more effective to control LBPB attacking groundnut.
\end{abstract}

Keywords - Pod borer; Entomopathogen; groundnut

\section{INTRODUCTION}

Lima bean pod borer (LBPB), Etiella zinckenella Treitschke, is one of the major insect pests of soybean in many parts of the world [1]. The importance of this species in Indonesia is noted in some publications [2], [3], [4]. It was reported recently that this species was also considered as serious pest of groundnut.

LBPB was first reported as causing severe pod damage on groundnut in Indonesia in 2008 [4], [6]. The damage incurred by LBPB was as high as $78 \%$ or more, and some groundnut fields even were abandoned because farmers would loss more due to harvesting cost.

From field experiment it was observed that high incidence of LBPB was occurred in different altitude from 0 - > $800 \mathrm{~m}$ asl., though, it was more serious at lower altitude [7]. Other report showing LBPB as a serious pest of groundnut was from field survey in West Sumatera [8] which indicated similar results.

In soybean, farmers relay much on chemical insecticide uses to control LBPB, with consequences of any deleterious impacts to the environment that follows if it is not wisely applied. Insecticide treatments to control LBPB on groundnut are not only ecologically unsafe, but also not practical due to concealed behavior of the larvae inside pods below soil surface. Systemic insecticide might be so but unsafe as it might leave unaccepted residue in harvested pods. Reference [9] stated that injudicious use of insecticide in soybean is not effective in controlling LBPB populations; instead it destroys natural enemies, especially parasitoids.

In groundnut, many farmers just ignore the incidence of this insect pest in field, with risk of losing yield. High incidence of pod damage has discouraged farmers to grow groundnut. It is clear that safer and more effective technology such as biological control is badly needed. 
There are many documented studies on the potency of using natural enemies, including entomopathogen to control insect pest populations [10], [11], [12]. However, there were only view intensive studies that examined the potency of natural enemy to combat E. zinckenella in soybean [13], let alone in ground nut [see 8]. Entomopathogen nematode (EPN) has been used to control many insect pest species with good results and has been produced in commercial scale [14], [15]. Infective juvenile (IJ) of EPN was reported as good biological control agent for soil dwelling or concealed insect pests [14]. Infective juvenile is $3^{\text {rd }}$ larval instar of EPN. We have examined local (i.e. native) isolates of EPN and was able to induce mortality on $3^{\text {rd }}$ LBPB larvae up to $80 \%$ or more (unpublished data), which is not much different from ones reported reference [16] and [17]. Though, we have not successfully mass produced them. There are several advantages of using EPN for insect pest control. EPN is more easily incorporated into integrated pest management program, due to its resemblance in behavior to insecticide or other chemicals use for plant protection. Technology for mass production is available. Field application of EPN may be done using similar defined standard methods and equipment to that of applying insecticides. Furthermore, it is compatible with many chemical insecticides [17].

In this paper we reported results of field trials to evaluate the effectiveness of introduced EPN, Steinernema carpocapsae, for controlling LBPB attacking groundnut. We compared EPM with chemical insecticide and control blank (no control measure).

\section{MATERIAL AND METHOD}

\section{A. Experimental Design and Treatment Applications}

Field trials were conducted in Faculty of Agriculture's Experiment Station, University of Bengkulu. The soil type is ultisol with $\mathrm{pH}$ of 4.5 as measured in dry season. This study was conducted in four trials (planting seasons). Seeds were sewed singly in $30 \mathrm{~cm}$ within and $20 \mathrm{~cm}$ between rows. The plants were fertilized with Urea, SP-36 and $\mathrm{KCl}$ at dosis of 70,125 and $70 \mathrm{ha}^{-1}$, respectively. Weeding was done as necessary.

The experiment plots were originally two trials of splitplot design with main plots of trap crop for LBPB and subplot of control applications, in the first year (2012) and two trials of control applications (Chemical insecticide, Crude extract of neem leaf) in complete block randomized design (RCBD), in the second year (2013). The trap crops incorporated in the first year trials were four rows of Crotalaria juncea or soybean, which was grown in a peripheral pattern (i.e. surrounding corresponding plots). The main plots, including control (without trap crop), were arranged in randomized block. Subplot treatments were EPN, EPN + crude extract of neem leaf, Deltametrin (Decis ${ }^{\circledR} 2.5$ EC), and control (blank). The treatments were replicated three times.

The main plots were of ca. $50 \mathrm{~m}$ x $20 \mathrm{~m}$, each was split into 4 subplots of $25 \mathrm{~m} \times 10 \mathrm{~m}$. EPN (S. carpocapsae) obtained from Biological Control Laboratory of Agriculture Faculty, University of Jember was applied twice at plant age of 45 and 65 days after sewing (DAS), at dose of $500.000 \mathrm{IJ}$ $\mathrm{m}^{-2}$. Infective juvenile of $S$. carpocasae was diluted into 12.5 1 and applied for $250 \mathrm{~m}^{-2}$ subplot and the applications were done with low pressure knapsack sprayer. EPN application using sprayer with static pressure until 14 bars did not injure the nematode. Furthermore, the passage through flat nozzle did not affect the viability of nematode infective juvenile [18]. Whereas, insecticide and neem extract were applied in 7 days interval at plant age of 35-70 DAS.

\section{B. Data Collection and Analysis}

LBPB incidence was observed every 2 weeks, at 63, 77, and 90 DAS, with 10 sample plants taken randomly. Observation was also done at harvest with 30 sample plants. Within each sample plant, all pods were inspected for the presence of damage sign (holes) and LBPB larvae. Undamaged pods taken from 30 plants that were sampled randomly at harvest were weighed per plant basis. Data were analysed with ANOVA and means were separated with least significant different (LSD).

In this report, the main plots (trap crops) were ignored due to their lack of effect on LBPB incidence. Neem leaf extract also was omitted because gave no addition effects as compared to EPN only. Therefore the data were pooled for statistical analyses comparing EPN, insecticide and control in randomized block design, which considered replications and control measures (EPN, Insecticide, and control) as variation sources.

\section{RESULTS AND DISCUSSION}

In general, the incidences of LBPB (damaged pods on groundnut) were very low, except for the last trial. We found only few larvae from sample plants, and therefore it is not included in this discussion. This low incidence does not support the notion that LBPB is one of the most important insect pests of groundnut as has been noted in several publications, e.g. [1], [2], [5]. Low LBPB incidence in our study was probably due to isolated location where trials were conducted that has never been use for legumes. The location was surrounded by oil palm plantation and secondary forest growth, and as such, population buildup of LBPB had never occurred in that area. In the fourth trial the population might have grown much higher after previous three consecutive trials and therefore caused more damage to pods (Fig 1).

Mean numbers of damage pods consistently tended to be less in plots treated with insecticides or EPN than those in controls. However the different was not statistically significant.

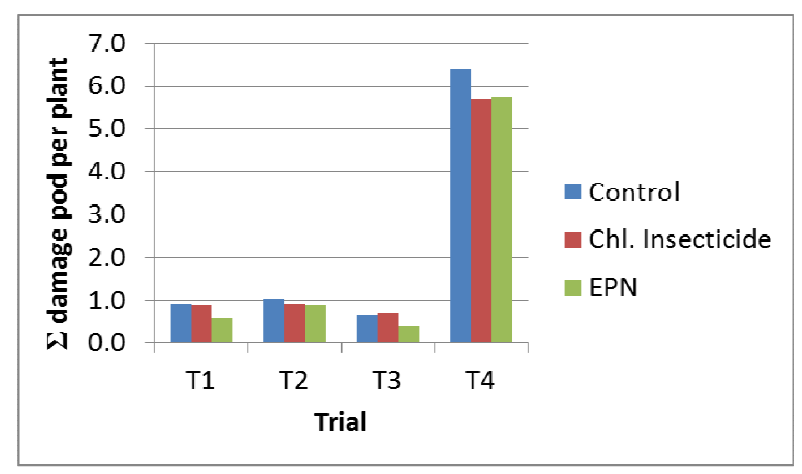

Fig 1. Number of damage pods by Etiella zinckenella in four filed trials. 
There are variations in undamaged pod yield, but not consistent between EPN or insecticide treated plots and control (Fig 2). In a field efficacy trial for diamondback moth control, reference [17] found larvae mortality up to $60 \%$ at day $7^{\text {th }}$, with EPN formulated in Water Dispersible Granules (WDG), suggesting that, to some extends, EPN is effective to control insect pest. Pod weight did not differed significantly between EPN or insecticide treated plots with those of controls. Pod production is much lower in the fourth trial. This was probably as a result of continuous use of the same location (plots) for groundnut growing.

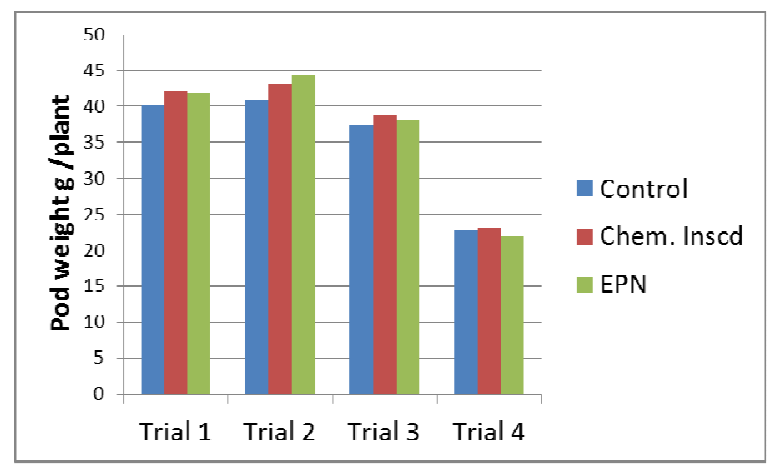

Fig 2. Per plant bases of pod weight in four trials

There are some explanations why EPN had not been able to reduce the incidence of LBPB significantly in our study. Reference [15] stated that nematode, host, and the environment as important factors that might influence field efficacy. In our trials, EPN resource was far away from the location of field trial, so that they suffered from shipment (e.g. packaging and long transportation). They were sent via carriages which toke 5 days to get our office. In laboratory observations, we found only $\pm 60 \%$ of IJ of EPN that were alive and further EPN mortality might be occur in field after being applied. We did not bioassay to determine their viability. In addition, the EPN isolate might be not quite adapted to local conditions. The soil $\mathrm{pH}$ where field trials were conducted was 4.5 (acid), which may be different from the origin of the strain of EPN used. The possible effect of soil $\mathrm{pH}$ has been suggested as important factor affecting natural occurrence of EPN [18], [20]. In additions, it might be also that the EPN is not quite adapted to often disturbed soil due to frequent tillage as has been mention in reference [16]. The effect of temperature was reported in [21] indicating that EPN infectivity increase with temperature with the highest larval mortality of $G$. mellonella by $S$. feltiae at $26^{\circ} \mathrm{C}$. We did not measure soil temperature in our study. Working with Heterorhabditis bacteriphora against tepitrid fruit fly, Anastrepa ludens, Reeference [22] in laboratory study reported that soil moisture also affected efficacy of EPN in infecting the third instar of the host. Mortality of $A$. ludens increased when the soil moisture was increase from $9 \%(\mathrm{w} / \mathrm{w})$ until $18 \%$, but then decrease at further higher moisture. We did not measure the soil moisture, but monthly rain fall was high within panting season both in 2012 and 2013, ranging from $288-632 \mathrm{~mm}$.

Efficacy of EPN is also affected by the method of application [23] who reported a field test comparing between two methods, irrigation versus gel formulated spray. Effective pest suppression was obtained in Gel spray, not in irrigation method.

Reference [14] cited that EPN efficacy for soil dwelling insects may be ineffective if behavior in host finding, attachment, or penetration by infective juvenile is reduced because of host behavior change. Host behaviors may evolve in the form of increasing defecation rate which my reduce EPN infection via anus. It may also in the form of $\mathrm{CO} 2$ output reduction or releasing $\mathrm{CO} 2$ in burst such that reducing chemical cues, or forming physical barrier in the form of impenetrable cocoons or soil cells before pupation.

Inasmuch that the difference was not significant, the facts that the LBPB tended to be lower in EPN than that in control plots might indicate that EPN effective against this insect species. Effort to use local isolate (strain) of EPN has been done in Bengkulu. We have explored and did bioassay local (native) isolate in our laboratory using $3^{\text {rd }}$ LBPB larvae that resulted $80 \%$ mortality (unpublished data). However mass production has not been success due to failure in isolating and culturing of bacterial symbiont, Xenorhabdus. This bacterium is one that is responsible in causing larval death of host. Infective juvenile of EPN releases the bacterial symbiont when infect larvae and consume the devoured tissue of infected larvae [16]. Larval death is a result of physiological changes of some immunity enzymes (e.g. phenoloxidase, acetylcholinesterase and carboxyilesterase), digestive enzyme (e.g. protease), and hydrolyzing enzymes (e.g. amylase, trehalase, invertase) within infected insect [24].

It is not practical to use the natural host (insects) for EPN mass-production (i.e. invivo), as it will be very laborious and costly. Invitro mass-production (i.e. in artificial diet + Xenorhabdus) of EPN has been successfully done in many laboratories, using different artificial diets [14]. However we have not been successful in isolating and culturing the bacterial symbiont. Without the bacterial symbiont the productivity of infective juvenile is very low and therefore unpractical. With the aforementioned conditions, it is necessary that local isolate of EPN and the bacterial symbiont be explored and studied, so that can used for LBPB biological control in any locality in this country. I speculate that local strain of EPN might be more effective to control LBPB attacking groundnut.

\section{CONCLUSIONS}

The incidence of LBPB in groundnut is alarming, especially in Sumatera. In new planting area the incidence might increase in several growing seasons. Steinernema carpocapsae have potency as biological control agent for combating LBPB attacking groundnut as had been seen by more or less consistence lower of damage pods in EPN treated plots than that of control. However, it needs further study to find and mass-produce effective local isolate(s).

\section{ACKNOWLEDGMENT}

This article is part of study funded by The Directorate General of Higher Education Republic of Indonesia, through "Unggulan Perguruan Tinggi" Research Grand 2012 and 2013. We would like to thank Mr. Wagiono, lecturer at the 
Faculty of Agriculture, University of Jember for providing Steinernema carpcapsae.

\section{REFERENCES}

[1] P.E.S. Whalley. "The Genus Etiella Zeller (Lepidoptera: Pyralidae : a Zoogeographic and Taxonomic Study". Bull. Br. Mus. Nat. Hist, (Ent), vol. 28, pp. 1-21. 1973.

[2] L.G.E. Kalshoven,. "Pests of Crops in Indonesia". P.T. Ichtiar BaruVan Hoeve, Jakarta. 1981.

[3] Y. Baliadi, W. Tengkano, dan Marwoto. "Soybean Pod Borer Kedelai, Etiella zinckenella Treitschke (Lepidoptera: Pyralidae), and Its Control Strategy in Indonessia”. J. Litbang Pertanian, vol. 27, pp. 113-123. 2008 (in Indonesian).

[4] H. Van Den Berg, B. M. Shepard and Nasikin. "Damage incidence by Etiella zinckenella in soybean in East Java, Indonesia". International Journal of Pest Management, vol. 44, pp. 153-159. 1998.

[5] D. Apriyanto, Sriwidodo, and Priyatiningsih. "Incidence of soybean pod borer on groundnut (Arachis hypogaea L.) in Bengkulu". J. Akta Agrosia, vol. 11, pp 40-45. 2008.

[6] D. Apriyanto,., E. Gunawan and T. Sunardi. "Resistance of some groundnut cultivars to soybean pod borer, Etiella zinckenella Treit.(Lepidoptera: Pyralidae)". J. Trop. Pest and Diseases, vol. 9, pp. 1-7. 2009.

[7] D. Apriyanto, B. Toha, Priyatiningsih, dan D. Suryati. 2010. "Resistance Performance of six Groundnut Varieties to Lima Bean Pod Borer (Etiella zinckenella Trietschke) in High and Low Altitudes in Bengkulu". J. of Tropical Pests and Diseases, vol. 10, pp. 13-19. 2010. (in Indonesian).

[8] Reflinaldon, Trizelia, Hasmiandy and Jamilah Ganeshi. "Pod Borer of Peanut and Potential Entomopathogenic Fungi for its Control in West Sumatera" Int. J. Advance Sci. Eng. Tech. Infor. Tech., vol. 4, pp. 53-57. 2014.

[9] H. van den Berg, A. Aziz, M. Machrus. "On-farm evaluation of measures to monitor and control soybean pod-borer Etiella zinckenella in East Java, Indonesia". Int. J. Pest. Management, vol. 46, pp. 219-224. 2000.

[10] R. Georgis a, A.M. Koppenhöfer, L.A. Lacey, G. Bélair, L.W. Duncan, P.S. Grewal, M. Samish, L. Tan, P. Torr, R.W.H.M. van Tol. "Successes and failures in the use of parasitic nematodes for pest control". Biological Control, vol. 38, pp. 103-123. 2006.

[11] M.Y. El-Kholy, A.S.H. Abdel-Moniem, H.M.A Abdelzaher. "Persistence of Entomopathogenic Nematodes and Fungi in Soil around Olive Trunks and Their Virulence to Zeuzera pyrina L." Egypt. Acad. J. Biolog. Sci., vol. 7, pp. 57-61. 2014.

[12] P.D. le Vieux, A.P. Malan. "Prospects for Using Entomopathogenic Nematodes to Control the Vine Mealybug, Planococcus ficus, in South African Vineyards". S. Afr. J. Enol. Vitic., vol. 36, pp. 59-70. 2015 .
[13] S. Herlinda, A. Rauf, U. Kartosuwondo dan Budihardjo. "Biology and potency of egg parasitoid, Trichogrammatoidea bactrae bactrae Nagaraja (Hymenoptera: Trichogrammatidae) for soybean pod borer control". Bul. Hama dan Peny. Tumb., vol. 9, pp. 19-25. 1997 (in Indonesian).

[14] S. Hazir, H.K. Kaya, S.P. Stock, N. Keskun. "Entomopathogenic Nematodes (Steinernematidae and Heterorhabditidae) for Biological Control of Soil Pests". Turk J. Biol., vol. 27, pp. 181-202. 2003.

[15] W.J. Schroeder. "Laboratory bioassays and field trials of entomogenous nematodes for control of Diaprepes abbreviates". Environ. Entomol., vol. 16, pp. 987-989. 1987.

[16] J.O. Nyasani, J.W. Kimenju, F.M. Olubayo, S.I. Shibairo and G.K. Mutua. "Occurrence of Entomopathogenic Nematodes and their potential in the management of diamontback moth in Kale". Asian J. of Plant Sciences, vol. 7, pp. 314-318. 2008.

[17] B.S. Sunanda, P. Jeyakumar and V.V. Jacob. "Bioefficacy of different formulations of entomopathogenic nematode Steinernema carpocapsae against diamond back moth (Plutella xylostella) infesting cabbage (Brassica oleracea var. capitata)". J. of Biopesticide, vol. 7, pp. 210-215. 2014.

[18] A. Lanzoni, G. Ade, R. Martelli, P. Radeghieri, F. Pezzi. "Technological aspects of Steinernema carpocapsae spray application alone or mixed with Bacillus thuringiensis aizawai in spinach crop" Bull. of Insectology, vol. 67, pp. 115-123. 2014.

[19] E.E. Lewis. "Behavioural ecology". R. Gaugler. Ed. Entomopathogenic Nematology. pp. 205-220. CAB International, Wallingford, Oxon, UK. 2002.

[20] P. Constant, L. Marchay, M. Fischer-Le-Saux, S. Briand-Panoma, and H. "Mauleon. Natural occurrence of entomopathogenic nematodes (Rhabditida: Steinernematidae and Heterorhabditidae) in Guadeloupe islands". Fundam. and Appl. Nematol., vol. 21, pp. 667672. 1998.

[21] M. Raheel, N. Javed, Z. Iqbal, H.M. Atif, S. Ahmad, E. Ashraf, I. Ahmad, A. Ali and M. Ehtsham-ul-Haq. "Talha plant pathology effect of temperature on the virulence of Steinernema Feltiae and Heterorhabditis bacteriophora against larval mortality of Galleria Mellonella”. Advances in Environmental Biology, vol. 9, pp. 371373. 2015.

[22] J. Toledo, J.E. Sánchez, T. Williams, A. Gómez, P. Montoya, and J.E. Ibarra. "Effect of soil moisture on the persistence And efficacy of Heterorhabditis bacteriophora (rhabditida: heterorhabditidae) against anastrepha ludens (diptera: tephritidae) larvae. Florida Entomologist, vol. 97, pp. 528-533. 2014.

[23] D.I. Shapiro-Ilan, T.E. Cottrell, R.F. Mizell, D.L. Horton, A. Zaid. "Field suppression of the peachtree borer, Synanthedon exitiosa, using Steinernema carpocapsae: Effects of irrigation, a sprayable gel and application method". Biological Control, vol. 82:7-12. 2015.

[24] S.A.M. Ibrahim, M.A Taha, H.H.A. Salem, and D. S. Farghaly. "Changes in enzyme activities in Agrotis ipsilon (Lepidoptera, Noctuidae) as a response to entomopathogenic nematode infection". International J. of Advanced Research, vol. 3, pp. 111-118. 2015. 